\title{
US academy study finds GM foods are safe...
}

\section{Washington}

There is no scientific evidence that crops that have been genetically modified to resist pests pose special health or environmental risks, according to a study released last week by the US National Research Council (NRC), the research arm of the National Academy of Sciences.

But the study - commissioned and paid for by the NRC in a bid to inject scientific views into the debate in the United States on the safety of genetically modified (GM) food - still recommends that US government agencies tighten the regulation of GM food.

For example, it calls on the Environmental Protection Agency (EPA) to reconsider two broad exemptions excluding viral-coat proteins and genes from sexually related plants from the regulations that the agency imposes on GM pest-resistant plants.

"Although the committee believes that generally the system is working well, we have identified needed improvements," says Perry Adkisson, an entomologist and former chancellor of Texas A \& M University, who chaired the NRC panel.

The study endorses the main conclusions of a 1987 National Academy of Sciences paper on the environmental impact of GM organisms (GMOs). This said that an organism's properties, rather than the process by which it was produced, were the key to its safety. This approach, which became key to the concept of 'substantial equivalence', formed the basis of the US government's regulation of GMOs.

However the new study calls for far more research into the environmental impacts of GMOs, and for greater coordination between the three US government agencies - the EPA, the Food and Drug Administration, and the Department of Agriculture - that regulate them. It calls on the agencies to establish a common database of GMO research.

Critics say that the report is inconsistent in endorsing substantial equivalence and then requesting special research into, and regulation of, GMOs. But panel members argue that public concerns make this necessary, even if GM foods are scientifically equivalent to traditional foods. "We need to make sure that the public has confidence in the technology," says Fred Gould, a panel member and professor of ecology at North Carolina State University.

Bruce Alberts, the president of the National Academy of Sciences, said last week that the study was the start of an effort to involve the scientific community in a broad public debate on GM foods. "It is very important that the voice of science be heard clearly," he said.

But even in advance of its publication, the study was dismissed by some environmental

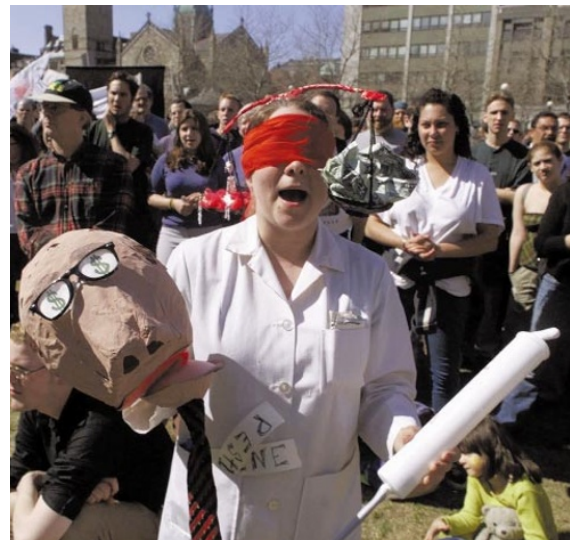

Public outcry: biotech protesters hoping to make their voices heard at a rally in Boston in March.

groups, who claimed that the panel was biased (see below). Dennis Kucinich (Democrat, Ohio), a congressman who has been critical of agricultural biotechnology, said the panel "leans overwhelmingly toward a pro-biotech position" and called on the academy to recall the report.

The biotechnology industry welcomed the findings. "This timely report... will reassure consumers on the thoroughness of the scientific scrutiny in place by US regulatory agencies," says Val Giddings, vice-president for food and agriculture at the Biotechnology Industry Organization.

NRC officials say the study is the first from the council to explicitly endorse the safety of GM foods. The 1987 study was concerned only with their impact on the natural environment.

The NRC also announced a new standing committee - co-chaired by Barbara Schaal of Washington University, St Louis, and Harold Varmus, former director of the National Institutes of Health and now president of the Memorial Sloan-Kettering Cancer Centre in New York - to "maintain surveillance" of agricultural biotechnology issues.

Colin Macilwain

\section{... but critics claim the panel was biased}

\section{Washington}

Even before the National Research Council (NRC) - the research arm of the National Academy of Sciences - released its report on genetically modified foods last week (see main story), pressure groups opposed to agricultural biotechnology were working to undermine it, arguing that panel members had conflicts of interest.

"The [academy] should hold the highest standards of independent scientific reporting, but this study absolutely does not meet those standards," said Andrew Kimbrell, director of the Washington-based Center for Food Safety, which campaigns against agricultural biotechnology, in a statement distributed outside the academy's headquarters, where about 30 protesters gathered on the morning of the study's release. "The blatant conflicts of interest with the biotech industry put this study in the category of "paid-for science'."

Environmental groups have been criticizing the study since last July, when Michael Phillips, the study's staff director, left to work for the Biotechnology Industry Organization. The NRC replaced him with another study

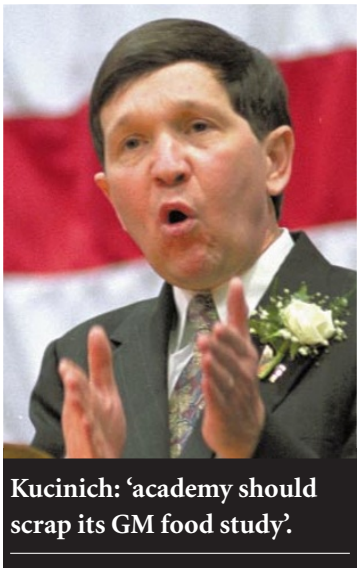

director, Jennifer Kuzma. Ever since, critics have called for the study to be abandoned, saying that the panel was biased.

In February, congressman

Dennis Kucinich (Democrat, Ohio) wrote to Bill Colglazier, executive director of the academy, describing what he regards as conflicts of interest on the study panel, and asking for the study to be scrapped.

Kucinich and his supporters charge that six of the 12 panel members have received research funds from the biotechnology industry or done consultancy or legal work on its behalf. For example, they say that Fred Gould has received research funds from Monsanto and Mycogen.

Gould points out that he has also taken money from the Union of Concerned Scientists and the Audubon Society, a conservation group. The literature distributed by groups opposing the study ignores this, say NRC officials, along with panel member Rebecca Goldburg's employment by the Environmental Defense Fund, a pressure group. The environmentalists say that Goldburg was added to the panel only after they objected to its original composition.

Eight of the panel are university researchers, and NRC says it is inevitable that they will have had grants from industry. Asked why he thought that the academy would rig its own panel, Kimbrell said it appeared to have been influenced by industrial contributions to its endowment fund.

"The academy allows itself to take outside money from corporations," he said. "Its panels are biased towards a corporate stance." An academy spokesperson denied that the contributions had had any impact on the composition of its panels, or their findings. 